\title{
The impact of Finno-Ugric languages in second language research: Looking back and setting goals
}

\author{
MINNA SUNI \\ University of Jyväskylä
}

\begin{abstract}
This state of the art review aims at discussing the potential relevance of Finno-Ugric languages in the larger context of second language research. Key results received in the studies conducted in the field of Finno-Ugric languages as second languages are introduced, and some interim conclusions based on them are made. The main areas in focus are cross-linguistic influence, forms and constructions, second language interaction, and motivation, identities and integration. Furthermore, some future lines of investigation are suggested for the researchers of the field. The research activities are recommended to get more closely bound to the internationally established or emerging paradigms, and research activities involving several Finno-Ugric languages are strongly encouraged. To promote international co-operation, some existing gaps or obvious needs for research are pointed out, and preliminary research initiatives are made.
\end{abstract}

Keywords: second language; methodology; learning theories; Finno-Ugric languages; Estonian; Finnish; Hungarian 


\section{Introduction}

Finno-Ugric languages are often referred to as small languages. If compared to such languages as the globally used English and the widely used Spanish, French or Chinese, they certainly are small, but among all the approximately 6000 languages of the world, at least Hungarian, Finnish and Estonian belong to the top 400 with more than million speakers.

Also such labels as "less widely taught language" are relevant as it comes to Finno-Ugric languages, at least in comparison with those large world languages that are much more commonly used and offered in schools and universities around the globe. It can be questioned, however, whether those less widely taught ones are automatically of less importance in the context of research as well. In this article, the relevance of researching Finno-Ugric languages as second languages will be discussed in the light of research outcomes and opportunities.

It is worth recognizing and acknowledging that Finno-Ugric languages may enable some research settings that are not available when for example only Germanic and Romanic or other Indo-European languages are involved - which often is the case - and that they may thus have a greater impact on theory validation and development that would be expected on the basis of their relative size or visibility in general.

Even if the research setting does not provide anything particularly unique in terms of linguistic features, there may still occur tendencies not noted before in other language environments, or observations confirming prior research results based on different data. In such current research paradigms as language ecology, the societal situations and language policies affecting the identities and goals of language learners are of specific interest, and it can be expected that for example the learning of Estonian or Hungarian in Estonia or Hungary has a different starting point, motive, goal and social impact if compared with for example learning English, French or Spanish either in countries where they are spoken or elsewhere. 
This paper thus aims at revealing the partially hidden relevance of Finno-Ugric languages in the larger context of second language research. This is done by making some interim conclusions based on the research done in the field of Finno-Ugric languages as second languages so far, and by predicting and suggesting some future lines of study and investigation. This synthesis does not aim to be comprehensive; instead, it aims at highlighting some key tendencies and core areas that have had or could have an impact on the international second language research as well. In this sense, the leading idea is to provide a state of the art type of review which could serve as a starting point for further discussion and shared strategic research planning across the researcher community involved. (See also Martin 2007.)

The review mainly covers papers published in scientific journals, proceedings and such monographs as doctoral dissertations ${ }^{1}$. Reports introducing educational arrangements, development projects or language policies are not included, nor are papers published in other than scientific journals. Some Master's theses and development projects are mentioned, however, to emphasize the fact that especially in Estonia and Hungary the growth of the research field has only rather recently begun and at this stage of development the theses serve as a valuable starting point for widening research activities (see also Pool 2010a).

It is quite obvious that many studies on language contact or bilingualism are of major interest and importance from the second language perspective. In the Finno-Ugric context these involve both contrastive studies focusing on particular linguistic phenomena, sociolinguistically oriented projects (e.g. ELDIA) or doctoral studies focusing on codeswitching and cross-linguistic intelligibility (e.g. Frick 2008; Kovács 2001; Praakli 2009; Rannut 2005; Zabrodskaja 2009b), not to mention studies focusing on bilingual first language acquisition (Hassinen 2002) or identities of bilingual individuals (Puskás 2009; Strazer 2011). To

1 In the case of doctoral studies in progress, only the name of the researcher and the university are mentioned. Dissertations under examination and articles under peerreview are referred to as 'forthcoming. 
delimit the review clearly to second language research, these perspectives are not scrutinized or discussed in any detail, but simply mentioned here as a fruitful source of relevant viewpoints largely applicable in studies in this specific field, too. Also the research and development work focusing on pedagogical practices is ignored this time; a review of its own would be needed to properly cover the activities in that area.

The main goal of this paper is simply to show that Finno-Ugric languages can be seen as one specific "operational environment" in which second language research is nowadays conducted, and that relatively much has actually been done and found in this field already. Models thus exist in sister languages, and many questions are shared by nature. The review follows some developmental lines of second language research paradigms, although not solely in chronological order.

It is apparent that the research done could and should be even more closely bound to the internationally established or emerging paradigms. This would pave the way for such research activities in which several Finno-Ugric languages are parallelly involved. To encourage international co-operation, some existing gaps or obvious needs for research will be pointed out, and preliminary research initiatives will be made in the end.

\section{From error analysis to interlanguage}

Errors tend to be very attractive in the field of language education, and correcting and preventing them seems to be a shared goal of many language learners and that of numerous language educators as well. Erroneous talk is often regarded as something to be avoided and as a cause of shame, although it has been shown and known since early 1980's that errors are actually a driving force and a necessary resource for learning, and it is largely unfair to blame learners for not knowing all at once.

Nowadays it is largely acknowledged, that errors reveal the path of learning, and that they really are a prerequisite for a successful learning process. The idea of learners' individual, gradually evolving linguistic systems was launched and also further developed by Corder (1967), 
and the concept of interlanguage was introduced by Selinker (1972). The concept highlights the step-by-step procedure each learner is following by constructing one's own individual language variety, which is gradually developing closer to the so-called target form of the language to be learnt. Before and partially parallelly with the early interlanguage studies there was an intensive period of Error Analysis in the field of second language research (see e.g. Larsen-Freeman \& Long 2011). It appeared, however, that by analyzing the errors that arise one can not avoid them at the later stages of the process or prevent them in other learners.

Although Error Analysis was at its most popular in the 1970's, it entered the Finno-Ugric research scene only later. Among the most comprehensive and systematic studies done within this framework has been the licentiate thesis written by Lähdemäki (1995), which deals with errors produced by Swedish-speaking learners of Finnish (see also Määttä 2011), and the dissertation of Pool (2007) partially focusing on the errors made by learners of Estonian. In Pool's study, also the idea of interlanguage is strongly present, however, and the outcomes offer a wide view on the features and processes involved in Estonian as a second language learning.

As expected, the idea of interlanguage has been a predominant starting point for studies in the field, but obviously error-analytic approaches are still quite appealing as the first methodological framework to start with. Counting and comparing errors is a rather straightforward and mechanical way of doing analysis, and it offers some insight into the gap between the learner's present level of skills and the target to be reached. Generally speaking, the usefulness of the results based on Error Analysis only can be questioned, and the overtly normative orientation has also deserved a lot of critique. On the other hand, within recent corpusbased research also new, much more detailed and focused methodological means for approaching the dynamics of errors have been introduced (see e.g. Ivaska \& Siitonen 2009; Spoelman 2011). These promising developments show that the idea of analysing errors can still find new, relevant forms. 


\section{Studies on cross-linguistic influence}

What preceded Error Analysis in the international second language research was Comparative Analysis which aimed at predicting problems and challenges encountered by speakers of a specific language who learn another language. The basic idea was to compare the systems and linguistic features of the (standard) languages -the source and the target language - and to find the main differences between them, since they were expected to cause more trouble than other features to be learnt. Comparative settings have been extremely popular within Finno-Ugric studies, although not primarily from the point of view of second or foreign language learning. It is quite logical and expectable that also text books designed for speakers of another Finno-Ugric language have typically contained a lot of comparative elements to show both the similarities and differences between the languages in question.

Recent studies focusing on cross-linguistic influence in second language learning can be regarded as grandchildren of such earlier orientations. Especially Annekatrin Kaivapalu's (2005) dissertation was tightly connected with the international research orientations represented by Jarvis (2000). Among the pioneers of the field is also Ringbom (e.g. 1987) who has shown how differently Finnish-speaking and Swedish-speaking Finns learn English due to the dissimilar linguistic relation their first languages have with the target language.

Kaivapalu (2005, see also 2009) has analyzed the ways in which students of Finnish, who have either Estonian or Russian as their first language, inflect Finnish nouns, and shown that Estonian speakers rely much more on the positive transfer and analogy available for them than Russian speakers, who do not have that option to the same extent and who therefore tend to rely primarily on rule-based processing instead. Kaivapalu has also noted that the source language influence is not an isolated phenomenon. In the inflectional process it acts in interaction with other factors such as the strength of morphophonological cues and the complexity, productivity and frequency of the inflectional pattern in the 
target language. Also such characteristics as the word length, familiarity and frequency have a role to play.

Marianne Spoelman (2011), has focused on the use of partitive case by Estonian learners of Finnish, and shown that both positive and negative first language influence occurs, but the latter decreases as the language proficiency develops. Her data was from the International Corpus of Learner Finnish. Kaivapalu and Eslon (2011), in turn, have shown that there is a similarity and symmetry of the cross-linguistic influence to be found when two corpora, the Estonian Interlanguage Corpus and the International Corpus of Learner Finnish are compared. The positive morphological influence of a closely related first language is thus symmetrical in Estonian and Finnish and acts in both directions.

Such findings are of obvious relevance in international second language research, and it is worth noting that there are hardly any other language combinations aside from those within Finno-Ugric languages that offer as varied views on cross-linguistic influence at the level of morphology. This is simply due to the vast variety of morphological and morphophonological features that can be analyzed in these languages (see also Kaivapalu \& Martin 2007).

Leena Nissilä (2011) has analyzed the impact which Estonian as the first language has on the learning of Finnish verbs and their linguistic government (rection). The main body of data consisted of translation tasks. Also this study shows that a closely related first language provides a relatively direct access to the second language system. In addition to high frequency of the words to be learnt, the saliency of linguistic government based on the first language system thus largely explains the experienced easiness of learning, at least in comparison with learners who lack this advantage. Also in Nissiläs study comparisons were made between Estonian and Russian-speaking learners of Finnish.

Pastuhhova (2005), in turn, has examined the transfer effects that Russian has on the spoken and written productions of Estonian as a second language. A partially corresponding approach with a different language pair has been present in Seilonen's (2008) study, in which she 
analyzed how Hungarian intermediate and advanced level learners of Finnish use impersonal verb forms in written texts. The results show that all main types of impersonality are already used at the intermediate level, and the means typical for spoken language tend to be replaced by more formal ones at the advanced level. In her forthcoming dissertation Seilonen broadens the scope to cover impersonal syntactic structures of written texts produced by beginning, intermediate and advanced learners of Finnish irrespective of their linguistic background. The data is derived from the Finnish National Foreign Language Certificate Corpus and the Cefling corpus of young writer (see Cefling), and a Construction Grammar perspective is partially applied in the analysis.

Object-marking by adult Hungarian speakers learning Finnish is the research topic in Erszébet Panka's forthcoming dissertation (Eötvös Loránd University, Budapest), which also has a strong contrastive orientation. Pool (2010b), in turn, has compared the object-marking by native speakers of Russian or Estonian. By bringing together a pair of different languages such studies offer a new perspective to the ways in which second language syntax develops, not only at the level of actual linguistic performance but also at the metalinguistic level.

Among the first internationally published studies on learning Hungarian as a second language is the article by Durst and Janurik (2011) which also has two Finno-Ugric languages involved and object marking as the main topic. In this study, one subgroup of informants had ErzyaMordvin as (one of) their first language(s) whereas the others had different first languages, and the second language was Hungarian. The test performed had a focus on definite conjugation in Hungarian, which has related but still different counterparts in Erzya-Mordvin. In contrast to what prior research results might suggest, no clear sign of positive crosslinguistic influence was found, however. What primarily seemed to explain the differences in performance was the time spent in the targetlanguage environment. This was especially clear in cases in which some contextual cues implying an implicit object should have been recognized. The researchers thus suggest that in the development of such highly com- 
plicated linguistic features as definite conjugation in Hungarian, exposure to input in real-life situations may be of pivotal importance. The relatedness of first and second language thus does not explain everything. Such a finding, in turn, is well in accordance with what Suni and Nieminen (2011) have suggested on the basis of their first and second language studies in Finnish: interaction can be seen as the breeding ground for the growth of complex morphology and morphosyntax (see also chapter 5).

\section{Forms and constructions}

Grammatical morphemes have received a lot of attention when investigating the key mechanisms involved in second language development. The so-called Natural Order Hypothesis was set in 1973 by Brown, who noticed that children acquiring English as their first language follow a similar order of acquisition of grammatical morphemes. Among the very limited number of grammatical morphemes available in English, those appearing early are -ing and plural markers, whereas the $-s$ marking of third person singular or possession comes significantly later to use. (See Brown 1973.) Soon after that, Dulay and Burt (1974) compared these findings with second language data to find that there are similarities between second language learners as well, but also differences in comparison with the first language results.

In general, the main attention in first and especially second language research has been on acquisition of English and its grammar. It is far more challenging to analyze the acquisition order of morphemes in any Finno-Ugric language, of course, since the amount of morphemes to be acquired is multiplied and their coordination is far from simple. Morphological development has been thoroughly investigated and described in Estonian, Finnish and Hungarian as a first language (see e.g. Slobin 1997), which obviously provides a firm basis for looking at similar processes within second language development as well.

Perhaps not surprisingly then, morphology has been the core area of research concerning Finno-Ugric languages as second languages. 
The first dissertation in the field was that of Maisa Martin (1995), who demonstrated that among second language learners, inflection of Finnish nouns is dependent on various competitive factors, and analogy is commonly employed instead of rules. Martin found connectionist models to be the most promising ones in explaining the studied phenomena. Later on, she has actively participated in the international discussion concerning such cognitive models as the Processability Theory (e.g. Pienemann 1998). As Martin (2004) has shown, findings based on Finnish as a second language partially support and partially challenge this theory; the most problematic part is how to situate the learning of morphophonological alternations in the model.

Kirsti Siitonen (1999), in turn, has analysed how agentless constructions based on automative verb derivations are faced by advanced learners of Finnish. In such a setting, the interplay between morphology, syntax and semantics provides almost maximal challenge for the learners. Syntax has not been focused on in that many studies yet, but the situation is changing (see e.g. Ivaska 2011; Metslang \& Matsak 2010). Especially interesting learners in this respect are second language users having sign language as their first language (see Herttuainen 2004; Tammelin 2001); their learning process should definitely receive more attention in the field.

As the previous chapter has already pointed out, Finno-Ugric grammatical features offer especially interesting insights for those interested in cross-linguistic influence in second language development. The overlapping morphological systems provide an exceptionally rich view of the cognitive processing of linguistic elements. Also the other end of the similarity-difference continuum is relevant, however; there are not many language pairs in the world that are typologically as distant from each other than for example Chinese and Hungarian or Vietnamese and Finnish.

This point of view has already attracted some attention in second language research. In their pioneering study based on variationist interviews with Chinese immigrants in Hungary, Langman and Bayley (2002) have revealed systemicity in the ways in which speakers of an analytic lan- 
guage acquire the verbal morphology of Hungarian. The leading forces are similar to other languages: frequency, salience, morphophonological regularity, and semantic complexity, the factor ruling over others being frequency. Also object marking was analyzed, and there was a preference for marking definiteness over indefiniteness.

Suni $(2007 ; 2008)$ has analyzed how Vietnamese learners of Finnish start to process receptively the inflectional morphology of Finnish in interaction. Their growing awareness of inflection is clearly reflected in their repetition practices, and the key finding is that receptive segmenting of inflectional morphology is a prerequisite for the productive use of it, when the first language of the learner is an isolating one. In addition, the findings refuted the prior results based on English as a second language data, which had suggested that morphology is never an overt target of negotiation in second language interaction.

The establishment of corpus-based second language research has opened up new opportunities for investigating linguistic forms and constructions employed by learners of different Finno-Ugric languages. Use of large text corpora allows effective, quantitatively grounded analyses on morphology, syntax and lexicon (see e.g. Eslon \& Metslang 2007; Ivaska \& Siitonen 2009; Jantunen 2009; Jantunen \& Piltonen 2009), but also demands careful consideration of the task effect and background information involved. A specific challenge, faced when broad data resources are available, is how to formulate research questions that are of obvious theoretical relevance, too, and that offer insights into the meta level of linguistic development.

Studies by Pille Eslon serve as a valuable model in many respects. In one of her analyses, Eslon (2009) has compared the preferences of case use in grammatical constructions occurring in Standard Estonian corpus and the Estonian interlanguage corpus, and found that the preferred case is the nominative in both language variants. Her results obviously speak for a construction grammar based approach to second language development; the use of individual forms is tightly connected to the actual, varying contexts in which they are used. Also the question of 
pedagogical relevance penetrates the discussions of Eslon's results (see Eslon 2007). Similarly, the analysis made by Kaivapalu and Eslon (2011) discusses the theoretically relevant question of symmetry in cross-linguistic influence and thus contributes to the international discussion on this particular issue. Jantunen (2008), in turn, has written about the aim of differentiating learner language universals from features specific for learners of certain linguistic backgrounds. This, again, is definitely not an empirical question only, but one that has roots in the entire international discussion on language universals and their relevance.

As a whole, corpus-based research may open up some new perspectives to old questions, and also offer answers that are of different nature than those received before. It can be argued, however, that corpus-based research is not a paradigm as such, but merely a fruitful set of methodologies employing specific types of data, either raw text or readily coded and annotated data. Various theoretical approaches are for instance adopted in the on-going doctoral studies in which learner corpora are analysed (e.g. Ilmari Ivaska, University of Turku; Kristi Pällin, University of Tallinn, and Marianne Spoelman, University of Oulu).

Interestingly enough, the Construction Grammar or Usage-based orientation has started to gain footing in the field of second language research (see e.g. Eskildsen 2008) almost simultaneously with the establishment of corpus-based metholology in the field. This is clearly not a coincidence, since these two fit well together. This turn is clearly taking place in the Finno-Ugric context as well, as the examples above illustrate.

Such an approach is partially applied in the project Paths in Second Language Acquisition (Topling, University of Jyväskylä) (see e.g. Alanen et al. 2012; Seilonen, forthcoming) which aims at comparing crosssectional and longitudinal sequences of the acquisition of writing skills in Finnish, English and Swedish as second languages in the Finnish educational system. The project explores the possibilities of combining three approaches to second language acquisition: linguistically based, proficiency-based, and task performance-based together. It is thus implemented in the crossroads of learning, testing and using the second 
language, which is quite a unique setting also in international comparison. Four dissertations (Mikko Kajander, Sanna Mustonen, Nina Reiman and Marja Seilonen) are currently in progress in the Finnish as a second language part of the project. Like the preceding project Cefling, also Topling has gained a lot of attention worldwide already. A related project has recently started in Estonia as well; in her study, Mare Kitsnik (University of Tallinn) examines the lexical and grammatical constructions occurring in the texts written by learners representing two different proficiency levels.

At the level of theorizing, second language research is actually now - finally -taking some promising steps towards a unified theory. The applications of Usage-based grammar can be seen as one step in this development, but those of Dynamic Systems Theory and Complexity theory, which in Natural Sciences is a part of the first mentioned, go even further. The conductors launching these approaches in second language study are, first and foremost, Kees de Bot and Diane LarsenFreeman, who in their shared paper (2011) have strongly argued for a dynamic and open nature of complex systems within second language development, which tend to interact across time and linguistic levels. They emphasize that the traditional paradigms can not describe and explain the continous interactions of various subsystems, which as such are adaptive and in constant change. Furthermore, they share the idea of socially situated and embodied cognition instead of an entirely individual and brain-centered cognition only. This means a radically different starting point if compared to the earlier, either cognition or interaction based models.

The first Dynamic Systems Theory based findings on Finnish as a second language have been reported already: in their longitudinal case study, Spoelman and Verspoor (2010) observed the variability in accuracy rates and various complexity measures. Also other studies are in progress within this framework: the doctoral study of Corinne Tilma, Universities of Jyväskylä and Groningen, and the project The long second: Longitudinal research in the development of Finnish as a second 
language in primary school preporatory class at the University of Helsinki. Related initiatives concerning Estonian and Hungarian would be more than welcome.

\section{Second language interaction}

Second language interaction has been a topic of several doctoral studies concerning adults learning and using Finnish (see Kurhila 2006; Lilja 2010; Suni 2008;). Kurhila and Lilja used Conversation Analysis as their method, whereas Suni implemented her microanalytic study in a dialogical framework. In all these studies, the focus was on the repair or negotiation sequences occurring in interaction and forcing the interlocutors to modify and clarify the forms mutually to reach a shared understanding and a common ground for further interaction.

The underlying theoretical questions of such settings have mainly been seen as related to the processing of linguistic forms in interaction. It has been argued since the early 1980's, when communication strategies and then negotiations of meaning became important foci of second language research, that those sequences which set a pressure to intensively process the form-meaning relationship either individually or, even more effectively, with a native speaker, tend to result in good learning outcomes. Such theorizing was concluded by Gass (1997) in the so-called IIO-model (Input, Interaction, Output), which highlighted the role of comprehensible input and output, and the strategies and negotiations facilitating the comprehensibility required. Such strategic aspects of second language use have been the focus of several studies on Estonian as a second language, for example Vihalemm (1999), Kikerpill \& Pool (2003), Garus (2006) and Pool (2007), and currently Pool is conducting research in the negotiations of meaning framework. Similar orientations have been present in some Finnish as a second language studies as well.

More recently, a broader, sociocultural framework (see e.g. Lantolf $\&$ Thorne 2006) has become relevant in the context of spoken second 
language interaction. Moreover, the related idea of participation in communities of practice (see Lave \& Wenger 1991) is found to be relevant from the same point of view, and it is thus commonly applied as well. Such approaches are thus present in both conversational analytic second language studies, also known as CA-for-SLA paradigm, which aims at a detailed description of learning occurring in talk-in-interaction (e.g. Lilja 2010) and more ethnographically oriented projects such as the Finnish as a work language project (University of Jyväskylä; see e.g. Suni 2010).

As the founder of socio-cultural research, Lev Vygotsky, argued in the 1930's, we learn from others by relying on their help. Learning thus inevitably has a social origin. Such thinking is even more broadly interpreted in the relatively new, ecological approaches to second language learning, which will be briefly discussed in the next chapter in relation to the motivational aspects, identity and integration, which also are important factors in second language development. Such viewpoints are already present in several studies, e.g. in the work language project mentioned above.

Mia Halonen (2009) has contributed to the discussion on interaction and learner identities from an exceptionally interesting perspective. Instead of using texts written in a second language as data for formfocused analysis, she has examined them as social interaction. In her sociolinguistically rooted study, she shows that spoken Finnish variants are actively used as a linguistic resource in written tasks by sixth-graders living in the Helsinki area, and the use of such features has multiple functions. By employing the resources available in spoken Helsinki Finnish one can reflect the identity work in progress, e.g. highlight the identity as a local resident and not primarily an immigrant, or show experience in interacting on-line in a second language. Also the students' perceptions of their own spoken language are present in the texts.

It is really worth noting that second language development is not only grammar and interaction. The process brings along multiple and even competing linguistic identities, resources and practices, and also a struggle for participation, integration and legitimacy. 


\section{Motivation, identity and integration}

Motivation has usually been analysed in terms of individual cognitive choices and preferences. Within Finno-Ugric language studies, only few researchers have focused on this theme, however. There are only some Master's theses in both Finland and Estonia (e.g. Borissenko 2009). The social dimensions of motivation (see Ushioda 2003) have thus not been investigated in any detail yet, although this might be of special and even international interest in the case of less widely taught languages. Csire and Laakso (2011, see also Laakso \& Csire forthcoming) have, however, discussed the question of Hungarian as a heritage language from a foreign or third language perspective, which serves as an interesting opening to this direction as well. How to justify to oneself and explain to others the desire and attempts to learn a language that is not widely recognized as a useful one, and what kind of impact does the possible lack of social appreciation or support have on the learning process and outcomes?

This also leads to the question of identity which has for some time been in the very core of sociolinguistic research in general, and is receiving increasing attention within second language researchers as well (see e.g. Kramsch 2009). In the Finno-Ugric context, identities have been topical in studies focusing on emigration (see e.g. Puskás 2009 and Strazer 2011 for recent examples and discussion), but not that much in relation to immigration yet.

Especially in the present stage of societal development in Finland, immigration has become a more central phenomenon, and consequently, the questions of integration, participation and belonging of immigrants ought to be dealt with in research as well. Finland changed from a country of emigration to that of immigration in the 1980's. The collapse of the Soviet Union, and the membership in the European Union had a boosting effect on immigration. Partially the same developments have resulted in an increase of immigration in Hungary as well, but had opposite effects in Estonia. Estonia already had a multilingual population, but many of its non-Estonian inhabitants moved back to their countries of 
origin after the collapse of the Soviet Union. The general societal situation should always be considered in terms of identity issues and opportunities for participation. According to current statistics, around 3 per cent of the total population in Finland and Hungary are speakers of other than the national languages. In Finland, the largest immigrant groups are speakers of Russian and Estonian, and more than 150 languages are spoken altogether. In Hungary, international immigration increased remarkably from the mid 1990s, but in the middle of the current economical tensions the future is unclear. The largest migrant groups come from the neighbouring countries, especially Romania, but there are thousands of Chinese and Vietnamese speakers, too, and immigration from Africa has also been rather steadily increasing. In Estonia, the number of emigrants is larger than that of immigrants; the country has lost approximately 15 per cent of its population since 1990, mainly due to the emigration trend among ethnic Russians, Ukrainians and Belarusians. As a whole, Russians make up one fourth of the population today, and in spite of the decline of the total population, linguistic diversity is more and more present due to international mobility. (Hungarian Central Statistical Office; Statistics Estonia; Statistics Finland; Melegh et al. 2005.)

In Estonia, the major concern among linguistic minorities have been the Russian speakers. Various identity issues concerning the large Russian-speaking population have been analysed by social scientists Triin Vihalemm and Veronika Kalmus (see e.g. Vihalemm 2007; Kalmus \& Vihalemm 2007; Vihalemm \& Kalmus 2008), and the question whether to learn the majority language or not has also been focused on (Vihalemm 2010). These highly complicated themes offer exceptionally fruitful settings for interdisciplinary inquiry as well, since there are numerous sociolinguistic and learning-related phenomena involved.

Also the Estonian language skills of the Russian-speaking minority have been focused on in several studies already (see e.g. Vihalemm 1999; Kikerpill \& Türk 2007). Of course, the history and status of the Russian speaking minority is quite different from that of immigrants. Immigrants are typically foreign citizens coming to work as labour 
migrants or, in some isolated cases, are asylum seekers or refugees living in Estonia (see e.g. Zabrodskaja 2009a). The complex, intertwining relations between language policies, second language development and multilingual identities have not been thoroughly investigated among the Russian speaking minority yet, but there are intensive research activities focusing on different aspects of this question in progress, as noted above (see also e.g. Pajusalu et al. 2010). Sooner or later, the same phenomena concerning immigrants from diverse language backgrounds will certainly receive more attention as well. The report by Kikerpill and Klaas (2006) focusing on immigrant children in Estonian education system is a promising sign of this.

In Finland, identities of Russian speaking adolescents - in this case immigrants - have been investigated in two dissertations so far (Iskanius 2006; Rynkänen 2011). Different profiles could be found: those who moved to Finland as teenagers identify themselves more as Russian language speakers than those who have been surrounded by Finnish since their early years. Partial rejection of or intensive adhesion to the Russian speaking community may vary across age and situation, but the majority perform bilingual identities; they have an access to both language communities and have a feeling of belonging to both of them.

The large research project Living conditions of immigrants (see Paananen 2005) showed that immigrants coming from Russia and Estonia have tighter social networks within Finnish speaking communities that Vietnamese and Somalian immigrants. They also assess their language skills higher, which is partially explainded by the relative closeness of the language and/or culture of origin. Anyway, it is clear that the social contacts have a role to play in the identity formation, participation and the development of language skills.

As briefly mentioned already, among the recent trends in linguistic inquiry is the ecological approach which looks at the language-related processes from a holistic point of view (see Kramsch 2008; van Lier 2004). "Ecology" refers to the interrelatedness between an individual and the surrounding social and physical environment. The language learner is 
seen as a part of the larger social system, but also as an active agent reacting to the different options and constraints faced in the environment. The Post-Soviet era societies, such as Estonia, would offer extremely interesting data for such holistic approaches which aim at understanding the complex wholes from policy level to individual choices and practices, and from linguistic landscapes to the biased attitudes towards the learning and use of the majority language. Such research would be of major international relevance, since developments with such drastic societal and policy level changes have hardly been experienced elsewhere but in the Baltic states within the last few decades.

It can be concluded that in Hungary and Estonia, the "newcomers" have received very little attention in research so far, especially as it comes to their language issues and identities. A very important exception, however, are the studies implemented by Nguyen Luu and her colleagues in Hungary (Nguyen Luu et al. 2009; Fülop et al. 2007). They reported a study based on a survey in which 218 Chinese mothers responded. The goal was to investigate integration and social support of Chinese immigrants living in four European countries: Hungary, Germany, United Kingdom and Spain, with a special focus on the group living in Hungary. This group had lower local language competence and a lower interest to communicate with the majority community. Family was seen as the primary source of social support, but school was the next. It offered valuable emotional, practical and informational support in all groups, but in Hungary to a lesser extent than in other countries. This can be interpreted to reveal that linguistic and social integration of immigrants is not as smooth a process in Hungary as it is elsewhere, and that the education system is not yet well prepared to receive students with immigrant background. Similar observations have been made by Csereklye and Nagy (2011; see also Feinschmidt \& Nyíri 2006), who interviewed teachers of immigrant students attending basic education classes in Hungary: there is an urgent need for tailored Hungarian as a second language materials and general development work in this field. A pioneering material set was also designed within the project in question. 


\section{Second language skills}

Language education and examination policies concerning immigrants have a different history and status in Finland, Estonia and Hungary, which is quite naturally reflected in the implementation of respective policies as well as in the research foci. Also the pedagogical traditions and practices of teaching Finnish, Estonian and Hungarian are somewhat different, but a relatively formalistic, morphology-centered view of language is obviously a shared feature and has to a large extent dominated in materials used and produced. A shift in pedagogy is taking place, however, and a more functionalist approach is now more commonly adopted (see e.g. Aalto et al. 2009; Csereklye \& Nagy 2011; Pool 2010a).

The recommendations of The Council of Europe, formulated in the Common European Framework of Reference for Languages (CEFR), are nowadays taken as a starting point for immigrant language education and standardized language proficiency testing in Estonia, Hungary and Finland. This might allow some interesting comparisons. Estonian language proficiency examination is organized by The National Examinations and Qualifications Centre (REKK, Riiklik Eksami- ja Kvalifikatsioonikeskus) in Estonia, Hungarian as a Second Language examinations are offered by the Centre for Foreign Languages (ITK, Idegennyelvi Továbbképző Központ) in Hungary and National certificates (Yleiset kielitutkinnot) by the National Board of Education in Finland. In Estonia, the official language examination seems to have a growing role at the level of both policies and practices; testing procedures soon cover all levels from basic education to employment; CEFR is the basis of compulsory assessment of the Estonian language proficiency of individuals, and skill requirements of all public servants and employees are also set according to its scale (see REKK; Zabrodskaja 2009a).

Several studies based on the test results have been implemented in Finland (see e.g. Tarnanen \& Pöyhönen 2011), but not yet in the other two countries discussed here. The Finnish results concerning immigrants clearly show that pre-test self-evaluation and standardized test results are generally in accordance with each other, and that speaking 
skills and receptive skills develop faster than writing skills on average. Finnish National Foreign Language Certificate Corpus based on the test takers' oral and written productions also allows detailed qualitative analyses, which already are in progress within the Topling project mentioned above. The Finnish as a second language test which is a part of the matriculation examinations has offered valuable data for analysis of written language skills as well (Komppa, forthcoming).

In addition to these viewpoints, the question of sufficient language skills is under debate in Finland especially in relation to employment (see e.g. Kokkonen 2009; Suni 2010); it is to be noted that field-specific regulations are not as common in Finland as in Estonia, for example. Research on these themes has started also in the Estonian context: Kikerpill and Türk (2007) have examined how professional language skills of Russian-speaking students in vocational education develop during the time spent in Estonian language environment. Especially self-assessments show that meaningful interaction leads to an overall improvement in Estonian language use and higher self-confidence. As for developing language tests for specific purposes, the importance of texts, task types and context was stressed.

\section{Further directions}

As the review has shown so far, many areas of second language development are at least touched upon if not well covered among the research activities concerning Finno-Ugric languages. What obviously still needs to be done, is to react to such new emerging paradigms as Dynamic Systems Theory and ecological perspectives, and consider the relevance of Finno-Ugric languages within them from multiple perspectives. In this respect, some promising research initiatives have been launched already, but only in the Finnish context and with a restricted scope until now.

The same is true in the context of CA for SLA research paradigm, which has already found a stable footing at least in Finnish language research. It would be valuable to broaden the scope to cover also other 
Finno-Ugric languages in this paradigm. What is also missing are detailed analyses of second language learning and use by young learners of any of the Finno-Ugric languages. The focus has been almost entirely on adults or adolescents.

As it comes to the societal factors and multilingually oriented second language research, many of the on-going studies and projects in neighbouring fields, especially in sociolinguistic (e.g. ELDIA and doctoral studies on code-switching and translingual intelligibility), will certainly serve as valuable source of information and offer reasons for a closer co-operation. Multiliteracies and multicompetences are a growing area of study internationally, and these themes will certainly bring together the researchers of second language learning and multilingualism in the future. Also here, the young learners would be of specific interest.

What is still lacking entirely are studies focusing on the smaller Finno-Ugric languages as second or foreign languages, such as Mordvin, Mari, Komi and Udmurt, or Sámi and Karelian. These languages are studied as foreign languages especially by students of Finno-Ugric departments across Europe, but no research has focused on the crosslinguistic influence or other particular features present in the learning process so far. Narrative or introspective case study methods would offer valuable information concerning the ways in which learners of these languages perceive the task of learning, and how they relate these languages to other Finno-Ugric languages they probably know as first, second or foreign languages in advance, as commonly is the case.

Also the motivational aspects are of growing interest: learning a relatively small or perhaps even endangered language is inevitably rooted in individual language policies and choices which go overtly against the mainstream preferences. As marginal as such a viewpoint might appear at the first sight, it opens new perspectives to such learning-related issues as cross-linguistic influence and morphological awareness only studied in limited language pairs before, as well as interesting questions about ownership, legitimacy and participation of the multilingual language learner and user. 
What would definitely be worth launching are larger projects bringing together more than two Finno-Ugric languages and combining multiple learning-oriented and societal perspectives in a well grounded theoretical and methodological framework. It is also quite obvious that to avoid a too narrow and only local awareness and applicability of the research results received within this particular field of second language research, the findings should be more actively made available for a larger international audience as well.

\section{Acknowledgements}

I am grateful to the two anonymous reviewers for their insightful comments. Also Erzsébet Csereklye, Annekatrin Kaivapalu, Tiina Kikerpill, Johanna Laakso and Raili Pool have provided valuable information during the writing process.

\section{References}

Aalto, Eija, Sanna Mustonen, Kaisa Tukia 2009. Funktionaalisuus toisen kielen opetuksen lähtökohtana. - Virittäjä 113 (3), 402-423.

Alanen, Riikka, Ari Huhta, Scott Jarvis, Maisa Martin, Mirja Tarnanen 2012. Issues and challenges in combining SLA and language testing research. Dina Tsagari, Ildikó Csépes (Eds.). Collaboration in Language Testing and Assessment. Language Testing and Evaluation Series 26. Frankfurt: Peter Lang, 15-30.

Board of Education. Yleiset kielitutkinnot. National certificates. http://www.oph. fi/koulutus ja tutkinnot/kielitutkinnot/yleiset kielitutkinnot (30.3.2012).

Borissenko, Olga 2009. Eesti keele õppe motivatsioon Tartu vene õppekeelega koolides. Unpublished MA thesis. Tartu: University of Tartu.

Brown, Roger 1973. A First Language. Cambridge: Harvard Press.

Cefling. https://www.jyu.fi/hum/laitokset/kielet/cefling (18.6.2012).

Corder, Pit S. 1967. The significance of learner's errors. - International Review of Applied Linguistics 5 (1-4), 161-170. http://dx.doi.org/10.1515/ iral.1967.5.1-4.161

Csereklye, Erzsébet, Judit Nagy 2011. Egütthaladó. Migránsgyremekek as iskolában. StepTogether - Migrant children at school. European Integration Fund, University of Miskolc. http://www.egyutthalado.uni-miskolc.hu/ english.html (3.4.2012). 
Csire, Márta, Johanna Laakso 2011. Teaching the heritage language as a foreign language: On the questions of bilingualism and minority language teaching in Austria. - ESUKA - JEFUL 2 (1), 93-108.

Dulay, Heidi S., Marina K. Burt 1974. Natural sequences in child second language acquisition. - Language Learning 24 (1), 37-53. http://dx.doi. org/10.1111/j.1467-1770.1974.tb00234.x

de Bot, Kees, Diane Larsen-Freeman 2011. Researching second language development from a dynamic systems perspective. - Marjorie Verspoor, Kees De Bot, Wander Lowie (Eds.). A Dynamic Approach to Second Language Development: Methods and Techniques. Amsterdam: John Benjamins, 5-24.

Durst, Péter, Boglárka Janurik 2011. The acquisition of the Hungarian definite conjugation by learners of different first languages. - Lähivõrdlusi. Lähivertailuja 21, 19-44. http://dx.doi.org/10.5128/LV21.01

ELDIA. European language diversity for all. http://www.eldia-project.org/ (30.3.2012).

Eskildsen, Søren W. 2008. Constructing another language - usage-based linguistics in second language acquisition. - Applied Linguistics 30 (3), 335-357. http://dx.doi.org/10.1093/applin/amn037

Eslon, Pille 2007. Õppijakeelekorpused ja keeleõpe. - Pille Eslon (Toim.). Tallinna Ülikooli keelekorpuste optimaalsus, töötlemine ja kasutamine. Tallinna Ülikooli eesti filoloogia osakonna toimetised 9. Tallinn: TLÜ Kirjastus, 87-120.

Eslon, Pille 2009. Eestikeelses tekstiloomes eelistatud konstruktsioonid ja käändevormid. - Pille Eslon, Katre Õim (Toim.). Korpusuuringute metodoloogia ja märgendamise probleemid. Tallinna Ülikooli eesti keele ja kultuuri instituudi toimetised 11. Tallinn: Tallinna Ülikool, 30-53.

Eslon, Pille, Helena Metslang 2007. Õppijakeel ja eesti vahekeele korpus. Eesti Rakenduslingvistika Ühingu aastaraamat 3, 99-116. http://dx.doi. org/10.5128/ERYa3.07

Feinschmidt, Margit, Pál Nyíri 2006. Nem kívánt gyerekek? Külföldi gyerekek magyar iskolákban. Budapest: Sík Kiadó.

Frick, Maria 2008. Morphological integration of Estonian lexical elements in a Finnish language base during the first years of immigration. - Journal of Linguistic and Intercultural Education 1, 81-95.

Fülöp, Márta, Robin Goodwin, Kerstin Goebels, Hector Grad, Luisa Martin Rojo, Lan Anh Nguyen Luu, Miháy Berkics 2007. Integration of Chinese immigrant children in four countries: Germany, Hungary, Spain and the UK. Ross Alistair (Ed.). Citizenship Education in Society. CiCe Conference Papers 2007. London: London Metropolitan University, 331-343. 
Garus, Jelena 2006. Keelekümblusrühmas ja eesti rühmas õppivate venekeelsete laste suhtlemisstrateegiatest. Unpublished MA thesis. Tartu: University of Tartu.

Gass, Susan M. 1997. Input, Interaction, and the Second Language Learner. Mahwah, NJ: Lawrence Erlbaum Associates.

Halonen, Mia 2009. Puhutun kielen variantit resurssina monikielisten koululaisten kirjoitelmissa. - Virittäjä 113 (3), 329-355.

Hassinen, Sirje 2002. Simultaaninen kaksikielisyys. Läheiset sukukielet viro ja suomi rinnakkain. Acta Universitatis Ouluensis B43. Oulu: University of Oulu.

Herttuainen, Päivi 2004. Sanajärjestys viittomakielisten suomen kielessä. Viittomakielisten informanttien lauseita täydennystehtävässä. Unpublished MAthesis. Jyväskylä: University of Jyväskylä.

Hungarian Central Statistical Office. http://portal.ksh.hu/ (30.3.2012).

Iskanius, Sanna 2006.Venäjänkielisten maahanmuuttajaopiskelijoiden kieli-identiteetti. Jyväskylä Studies in Humanities 5. Jyväskylä: University of Jyväskylä.

ITK = Idegennyelvi Továbbképző Központ. http://www.itk.hu (30.3.2012).

Ivaska, Ilmari 2011. Lausetyyppien sekoittuminen edistyneessä oppijansuomessa näkökulmana eksistentiaalilause. - Lähivõrdlusi. Lähivertailuja 21, 65-85. http://dx.doi.org/10.5128/LV21.03

Ivaska, Ilmari, Kirsti Siitonen 2009. Syntaktisesti koodattu oppijankielen korpus: mahdollisuuksia ja kysymyksiä. - Pille Eslon, Katre Õim (Toim.). Korpusuuringute metodoloogia ja märgendamise probleemid. Tallinna Ülikooli eesti keele ja kultuuri instituudi toimetised 11. Tallinn: Tallinna Ülikool, $54-71$.

Jantunen, Jarmo H. 2008. Haasteita oppijankielen korpusanalyysille: oppijankielen universaalit. - Pille Eslon (Toim.). Õppijakeele analüüs: võimalused, probleemid, vajadused. Tallinna Ülikooli eesti filoloogia osakonna toimetised 10. Tallinn: Tallinna Ülikool, 67-92.

Jantunen, Jarmo H. 2009. Ei pelkästään mielikuvituksen puutteen vuoksi. Kieliaineistojen systemaattinen käyttö kielentutkimuksessa. - Virittäjä 113 (1), 101-113.

Jantunen, Jarmo Harri, Saana Piltonen 2009. Oppijansuomen ja viron sähköiset tutkimusaineistot. - Virittäjä 113 (3), 449-458.

Jarvis, Scott 2000. Methodological rigor in the study of transfer: Identifying L1 influence in the interlanguage lexicon. - Language Learning 50 (2), 245-309. http://dx.doi.org/10.1111/0023-8333.00118 
Kaivapalu, Annekatrin 2005. Lähdekieli kielenoppimisen apuna. Jyväskylä Studies in Humanities 44. Jyväskylä: University of Jyväskylä.

Kaivapalu, Annekatrin 2009. Vironkielisen suomenoppijan äidinkieli - ongelma, haaste vai voimavara? - Virittäjä 113 (3), 382-401.

Kaivapalu, Annekatrin, Maisa Martin 2007. Morphology in transition: The plural inflection of Finnish nouns by Estonian and Russian learners. - Acta Linguistica Hungarica 54 (2), 129-156.

Kalmus, Veronika, Triin Vihalemm 2007. Changes in young people's self-identification and value structures in transitional Estonia. - Martti Muukkonen, Tiina Sotkasiira (Eds.). Young People at the Crossroads. Joensuu: University of Joensuu, 45-55.

Kikerpill, Tiina, Birute Klaas 2006. New immigrant children in the Estonian educational system. - Andrew Hancock, Susanne Hermeling, John Landon, Andrea Young (Eds.). Building on Language Diversity with Young Children. Teacher Education for the Support of Second LSanguage Acquisition. Zürich: Lit Verlag GmbH \& Co, 167-180.

Kikerpill, Tiina, Raili Pool 2003. Muutused eesti keelt teise keelena kõnelejate suhtlusstrateegiate kasutuses ühe aasta jooksul. - Pirkko Muikku-Werner, Hannu Remes (Toim.). VIRSU. Viro ja suomi: kohdekielet kontrastissa. Lähivertailuja 13. Joensuu: University of Joensuu, 50-60.

Kikerpill, Tiina, Ülle Türk 2007. Ametikeele oskuse mõõtmine: tekst ja ülesanne eesti keele kui teise keele kuulamistestis. - Eesti Rakenduslingvistika Ühingu aastaraamat 3, 177-191. http://dx.doi.org/10.5128/ERYa3.12

Kokkonen, Marja 2009. Työelämän kielitaito ja ääntäminen: työnantajien havaintoja. - Jyrki Kalliokoski, Tuija Nikko, Saija Pyhäniemi, Susanna Shore (Toim.). Puheen ja kirjoituksen moninaisuus - The diversity of speech and writing. Jyväskylä: AFinLA, 97-118.

Komppa, Johanna 2012. Retorisen rakenteen teoria suomi toisena kielenä -ylioppilaskokeen kirjoitelman kokonaisrakenteen ja kappalejaon tarkastelussa. Helsinki: University of Helsinki.

Kovacs, Magdolna 2001. Code-switching and language shif in Australian Finnish in comparison with Australian Hungarian. Turku: Abo Akademi University Press.

Kramsch, Claire 2008. Ecological perspectives on foreign language education. - Language Teaching 41 (3), 389-408. http://dx.doi.org/10.1017/ $\underline{\text { S0261444808005065 }}$

Kramsch, Claire 2009. The Multilingual Subject. Oxford: Oxford University Press. Kurhila, Salla 2006. Second Language Interaction. Amsterdam: John Benjamins. 
Laakso, Johanna, Márta Csire (forthcoming). L3, L1 or L9? Heritage-language students third-language learners. - Gessica de Angelis, Agnieszka Otwinowska-Kasztelanic (Eds.). Proceedings of the Seventh International Conference on Third Language Acquisition and Multilingualism (Warsaw 2011). Clevedon: Multilingual Matters.

Langman, Juliet, Robert Bayley 2002. The acquisition of verbal morphology by Chinese learners of Hungarian. - Language Variation and Change 14 (1), 55-77. http://dx.doi.org/10.1017/S0954394502141032

Lantolf, James P., Steven L. Thorne 2006. Sociocultural Theory and the Genesis of Second Language Development. Oxford: Oxford University Press.

Larsen-Freeman, Diane, Michael H. Long 1991. An Introduction to Second Language Acquisition Research. London: Longman.

Lave, Jean, Etienne Wenger 1991. Situated Learning: Legitimate Peripheral Participation. Cambridge: Cambridge University Press.

Lilja, Niina 2010. Ongelmista oppimiseen. Toisen aloittamat korjausjaksot kakkoskielisessä keskustelussa. Jyväskylä Studies in Humanities 146. Jyväskylä: University of Jyväskylä.

Lähdemäki, Eeva 1995. Mikä meni pieleen? Ruotsinkielisten virheet suomen ainekirjoituksessa. Unpublished licentiate thesis. Åbo Akademi.

Martin, Maisa 1995. The Map and the Rope. Finnish Nominal Inflection as a Learning Target. Studia Philologica Jyväskyläensia 38. Jyväskylä: University of Jyväskylä.

Martin, Maisa 2004. Three structures of Finnish and the Processability Theory. Lena Ekberg, Gisela Håkansson (Eds.). Nordand 6. Sjätte konferensen om Nordens språk som andraspråk. Lund: Lunds Universitet, Institutionen for nordiska språk, 201-212.

Martin, Maisa 2007. A square peg into a round hole? Fifteen years of research into Finnish as a second language. - Nordand 1, 63-85.

Melegh, Attila, Elena Kondrateva, Perttu Salmenhaara, Annika Forsander, László Hablicsek, Adrienn Hegyesi 2005. Globalisation, Ethnicity and Migration. The Comparison of Finland, Hungary and Russia. - Demografia - English edition 2005, 123-167.

Metslang, Helena, Erika Matsak 2010. Kesksete lausekomponentide järjestus õppijakeeles: arvutianalüüsi katse. - Eesti Rakenduslingvistika Ühingu aastaraamat 6, 175-193. http://dx.doi.org/10.5128/ERYa6.11

Määttä, Tuija 2011. Ruotsinkielisten alkeistason suomenoppijoiden paikallissijojen käytöstä. - Lähivõrdlusi. Lähivertailuja 21, 154-182. http://dx.doi. org/10.5128/LV21.07 
Nguyen Luu, Lan Anh, Márta Fülöp, Robin Goodwin, Kerstin Göbel, Luisa Martín Rojo, Hector Grad, Mihály Barkics 2009. Kínai bevándorló családok és gyerekeik integrációja és szociális támogatottsága. - Magyar Pszichológiai szemle 64 (1), 1-18.

Nissilä, Leena 2011. Viron kielen vaikutus suomen kielen verbien ja niiden rektioiden oppimiseen. Acta Universitatis Ouluensis. Humaniora 99. Oulu: University of Oulu.

Paananen, Seppo (Ed.) 2005. Maahanmuuttajien elämää Suomessa. Helsinki: Statistics Finland.

Pajusalu, Renate, Karl Pajusalu, Birute Klaas, Virve Vihman 2010. Forms of address across languages: Formal and informal second person pronoun usage among Estonia’s linguistic communities. - Intercultural Pragmatics 7 (1), 75-101. http://dx.doi.org/10.1515/iprg.2010.004

Pastuhhova, Olga 2005. Interferentsivead vene üliõpilaste suulise ja kirjaliku eesti keele süntaksis. - Raili Pool (Toim.). Teine keel. Uurimusi eesti keele kui teise keele omandamisest. Tartu Ülikooli eesti keele (võõrkeelena) õppetooli toimetised 5. Tartu: Tartu Ülikooli Kirjastus, 75-110.

Pienemann, Manfred 1998. Language Processing and Second Language Development: Processability Theory. Amsterdam: John Benjamins.

Pool, Raili 2007. Eesti keele teise keelena omandamise seaduspärasusi täis- ja osasihitise näitel. Tartu: Tartu University Press.

Pool, Raili 2010a. Eesti keele teise keelena uurimine Tartu Ülikoolis - hetkeseis ja perspektiivid. - ESUKA - JEFUL 1 (1), 5-20.

Pool, Raili 2010b. Vene ja eesti üliõpilaste valikud täis- ja osasihitise kasutamisel. - Lähivõrdlusi. Lähivertailuja 20, 191-216. http://dx.doi.org/10.5128/ $\underline{\text { LV20.06 }}$

Praakli, Kristiina 2009. Esimese põlvkonna Soome eestlaste kakskeelne keelekasutus ja koodikopeerimine. Tartu: Tartu Ülikool.

Puskás, Tünde 2009. "We belong to them": Narratives of belonging, homeland and nationhood in territorial and non-territorial minority settings. Brussels: Peter Lang.

Rannut, Ülle 2005. Keelekeskkonna mõju vene õpilaste eesti keele omandamisele ja integratsioonile Eestis. Tallinna Ülikooli humanitaarteaduste dissertatsioonid 14. Tallinn: TLÜ Kirjastus.

REKK = Riiklik Eksami- ja Kvalifikatsioonikeskus. http://www.ekk.edu.ee/ (29.3.2012).

Ringbom, Håkan 1987. The Role of the First Language in Foreign Language Learning. Clevedon: Multilingual Matters. 
Rynkänen, Tatjana 2011. Русскоязычные молодые иммигранты в Финляндии - интеграция в контексте обучения и овладения языком. Jyväskylä Studies in Humanities 168. Jyväskylä: University of Jyväskylä.

Seilonen, Marja 2008. Személytelen kifejezések a magyar anyanyelvű finntanulók írásaiban. - Edit G. Bogár (Szerk.). Kontrasztok. Ünnepi konferencia és kiállitás a pozsonyi Comenius Egyetem Magyar Nyelv és Irodalom Tanszékének 50 éves évfordulóján. Bratislava: Univerzita Komenského v Bratislava, 82-91.

Seilonen, Marja (forthcoming). Näkymätön ilmaiseminen. Yleistävyys oppijansuomen teksteissä. Dissertation. University of Jyväskylä.

Selinker, Larry 1972. Interlanguage. - IRAL 10, 209-230. http://dx.doi.org/10.1515/ iral.1972.10.1-4.209

Siitonen, Kirsti 1999. Agenttia etsimässä. U-verbijohdokset edistyneen suomenoppijan ongelmana. Turun yliopiston suomalaisen ja yleisen kielitieteen laitoksen julkaisuja 63. Turku: Turun yliopisto.

Slobin, Dan (Ed.) 1997. Study of Language Acquisition. Vol. 4. Mahwah, NJ: Lawrence Erlbaum.

Spoelman, Marianne 2011. The use of partitive predicatives by Estonian learners at different levels of L2 proficiency. - Lähivõrdlusi. Lähivertailuja 21, 280-304. http://dx.doi.org/10.5128/LV21.11

Spoelman, Marianne, Marjolijn Verspoor 2010. Dynamic patterns in development of accuracy and complexity: A longitudinal case study in the acquisition of Finnish. - Applied Linguistics 31 (4), 532-553. http://dx.doi.org/10.1093/ applin/amq001

Statistics Estonia. http://www.stat.ee/ (30.3.2012).

Statistics Finland. http://stat.fi/ (30.3.2012).

Strazer, Boglárka 2011. "Ungerska för rötternas skull”: Språkval och identitet bland andragenerationens ungrare i Sverige och Finland. Studia Uralica Upsaliensia 38. Uppsala: University of Uppsala.

Suni, Minna 2007. Awareness of second language inflectional morphology: A case study of Finnish as a second language. - Acta Linguistica Hungarica 54 (2), 217-235. http://dx.doi.org/10.1556/ALing.54.2007.2.6

Suni, Minna 2008. Toista kieltä vuorovaikutuksessa. Kielellisten resurssien jakaminen toisen kielen omaksumisen alkuvaiheessa. Jyväskylä Studies in Humanities 96. Jyväskylä: University of Jyväskylä.

Suni, Minna 2010. Työssä opittua. Työntekijän näkökulma ammatilliseen kielitaitoonsa. - Mikel Garant, Mirja Kinnunen (Toim.). AFinLA-e: Soveltavan kielitieteen tutkimuksia 2. Jyväskylä: AFinLA, 45-58. 
Suni, Minna, Lea Nieminen 2011. Complexity and interaction: comparing the development of L1 and L2. - ESUKA - JEFUL 2 (2), 215-236.

Tammelin, Taina 2001. Suomi viittomakielisten toisena kielenä: verbirektioiden viidakossa. Unpublished MA-thesis. Jyväskylä: University of Jyväskylä.

Tarnanen, Mirja, Sari Pöyhönen 2011. Maahanmuuttajien suomen kielen taidon riittävyys ja työllistymisen mahdollisuudet. - Puhe ja kieli 4, 139-152.

Ushioda, Ema 2003. Motivation as a socially mediated process. - David Little, Jennifer Ridley, Ema Ushioda (Eds.). Towards a Learner Autonomy in the Foreign Language Classroom: Teacher, Learner, Curriculum and Assessment. Dublin: Authentik, 90-102.

van Lier, Leo 2004. The Ecology and Semiotics of Language Learning: A Sociocultural Perspective. New York: Springer.

Vihalemm, Triin 1999. Estonian language competence, performance and beliefs on acquisition among the Russian-speaking inhabitants of Estonia 19891995. - International Journal of Sociology of Language 139, 69-85.

Vihalemm, Triin 2007. Crystallizing and emancipating identities in post-communist Estonia. - Nationalities Papers 35 (3), 477-502. http://dx.doi. org/10.1080/00905990701368738

Vihalemm, Triin 2010. To learn or not to learn? Dilemmas of linguistic integration of Russians in Estonia. - Ethnicity 2 (3), 74-98.

Vihalemm, Triin, Veronika Kalmus 2008. Mental structures in transition culture: Differentiating patterns of identities and values in Estonia. East European Politics and Societies 22 (4), 901-927. http://dx.doi. org/10.1177/0888325408316537

Vygotsky, Lev 1978 (1934). Thought and Language. A. Kozulin (Trans.). Cambridge, MA: The MIT Press.

Zabrodskaja, Anastassia 2009a. Language testing in the context of citizenship and asylum: The case of Estonia. - Language Assessment Quarterly 6 (1), 61-70. http://dx.doi.org/10.1080/15434300802606572

Zabrodskaja, Anastassia 2009b. Russian-Estonian language contacts: grammatical aspects of language use and change. Tallinn: Tallinna Ülikooli Kirjastus.

\author{
Minna Suni \\ University of Jyväskylä, Department of Languages \\ P.O.Box 35 \\ 40014 Jyväskylä, Finland \\ minna.suni@jyu.fi
}




\title{
Suomalais-ugrilaisten kielten anti toisen kielen tutkimukselle
}

\author{
MINNA SUNI \\ Jyväskylän yliopisto
}

Artikkelissa tarkastellaan sitä, millainen relevanssi suomalais-ugrilaisilla kielillä on ollut ja voisi olla toisen kielen tutkimuksen kentässä. Kyseessä on tilannekatsaus alan tutkimuksen painopisteistä, teoreettisista orientaatioista ja menetelmävalinnoista. Artikkelin loppupuolella tehdään myös muutamia ehdotuksia tuleviksi tutkimuksen lähtökohdiksi ja kohteiksi.

Tarkastelu on rajattu ensisijaisesti kieltenvälisen vaikutuksen, kielen rakennepiirteiden ja konstruktioiden oppimisen, toisella kielellä käytävän vuorovaikutuksen sekä motivaation, oppijaidentiteettien ja integroitumisen tarkasteluun. Myös virhenanalyyttista ja välikielinäkökulmaa sekä kielitaidon kysymyksiä sivutaan. Esimerkiksi kielipedagogiikkaa koskeva tutkimus ja keskustelu sekä toisen kielen oppimiseen liittyvät kehittämishankkeet on sen sijaan rajattu tarkastelun ulkopuolelle; nämä ansaitsisivat aivan oman vastaavan tilannekatsauksensa.

Artikkelin keskeinen väittämä on se, että huolimatta suhteellisesta pienuudestaan suomalais-ugrilaiset kielet ovat tarjonneet ja voivat tulevaisuudessakin tarjota toisen kielen tutkimukseen sellaisia näkökulmia, joita ns. suurten kielten tutkimuksessa ei voida tarkastella lainkaan tai ainakaan samassa mitassa. Tähän mennessä tällainen alue on ollut erityisesti morfologian oppiminen; suomalaisugrilaiset kielet sisältävät taivutusmorfologian osalta toki paljon enemmän ja monipuolisempaa opittavaa ja samalla myös tutkittavaa kuin esimerkiksi germaaniset kielet. On myös tärkeää, että tutkimustuloksia tuodaan kansainväliseen tietoisuuteen. Parhaimmillaan esimerkiksi suomen, viron tai unkarin oppijoiden kielimuotoja analysoimalla voidaan haastaa tai jopa oikaista alan teorioita, joita usein edelleen vaivaa englantikeskeisyyteen liittyvä vinouma. Niin ikään on olennaista pitää silmällä alalla vakiintumassa olevia teoreettisia virtauksia ja rakentaa tietoisesti sellaisia tutkimusasetelmia, joiden myötä eri teorioihin niihin on mahdollista ottaa kantaa myös suomalais-ugrilaisten 
kielten näkökulmasta. Nykyisin tällaisina voidaan pitää esimerkiksi käyttöpohjaisia malleja ja dynaamisten systeemien teoriaa.

Se erityisyys, jota suomalais-ugrilaisten kielten tutkimus voi tuoda alalle, ei suinkaan välttämättä rajoitu vain kielen rakennepiirteisiin. Myös yhteiskunnallinen tilanne voi sisältää tekijöitä, jotka muokkaavat esimerkiksi toisen kielen oppimisen sosiaalisesta tai koulutuksellisesta ympäristöstä erityisen kiinnostavan. Tämä pätee muun muassa Viroon, joka on käynyt läpi poikkeuksellisen suuren yhteiskunnallisen ja kielipoliittisen muutoksen viime vuosikymmenien aikana. Esimerkiksi ekologinen lähestymistapa kielenoppimiseen voisi holistisuudessaan soveltua hyvin tällaisten prosessien analyysiin ja ohjata tunnistamaan, miten yksilötason motiivit, oppijaidentiteetit ja kielellinen toiminta ovat yhteydessä yhteiskunnan kielipoliittisiin linjauksiin, koulutusjärjestelyihin ja ympäristön monikielisyyteen. Unkarissa taas maahanmuuttajien kielikysymykset ovat vasta hiljattain alkaneet nousta tutkimuskohteeksi, ja alan kehitykselle on epäilemättä eduksi, että vertailukohtia ja näkökulmia on löydettävissä myös sukukielten tutkimuksen piiristä.

On paikallaan nähdä suomalais-ugrilaisten kielten tarkastelu toisena kielenä myös sellaisena eri toimijoita yhdistävänä teemana, jonka ympärille tulevaisuudessa voitaisiin rakentaa yhteistyöhankkeita. Sellaisten kautta alan tutkimus saisi todennäköisesti myös lisää kansainvälistä näkyvyyttä.

Avainsanat: toinen kieli; tutkimusmenetelmät; kielenoppimisen teoriat; suomalais-ugrilaiset kielet; suomen kieli; unkarin kieli; viron kieli 